\title{
Comparison of transmission dynamics between Streptococcus uberis and Streptococcus agalactiae intramammary infections
}

\author{
Kansuda Leelahapongsathon, ${ }^{*}$ Ynte Hein Schukken, †‡ Tanu Pinyopummintr, § and Witaya Suriyasathaporn*1 \\ *Department of Food Animal Clinics, Faculty of Veterinary Medicine, Chiang Mai University, Mae Hea, Chiang Mai, Chiang Mai Province 50100, \\ Thailand \\ †Department of Population Medicine and Diagnostic Sciences, Cornell University, Ithaca, NY 14853 \\ ‡GD Animal Health, 7418EZ Deventer, the Netherlands \\ $\S$ Department of Large Animal and Wild Life Clinical Sciences, Kasetsart University, Bangkok 10900, Thailand
}

\begin{abstract}
The objectives of study were to determine the transmission parameters $(\beta)$, durations of infection, and basic reproductive numbers $\left(\mathrm{R}_{0}\right)$ of both Streptococcus agalactiae and Streptococcus uberis as pathogens causing mastitis outbreaks in dairy herds. A 10-mo longitudinal study was performed using 2 smallholder dairy herds with mastitis outbreaks caused by Strep. agalactiae and Strep. uberis, respectively. Both herds had poor mastitis control management and did not change their milking management during the entire study period. Quarter milk samples were collected at monthly intervals from all lactating animals in each herd for bacteriological identification. The durations of infection for Strep. uberis intramammary infection (IMI) and Strep. agalactiae IMI were examined using Kaplan-Meier survival curves, and the Kaplan-Meier survival functions for Strep. uberis IMI and Strep. agalactiae IMI were compared using log rank survivaltest. The spread of Strep. uberis and Strep. agalactiae through the population was determined by transmission parameter, $\beta$, the probability per unit of time that one infectious quarter will infect another quarter, assuming that all other quarters are susceptible. For the Strep. uberis outbreak herd (31 cows), 56 new infections and 28 quarters with spontaneous cure were observed. For the Strep. agalactiae outbreak herd (19 cows), 26 new infections and 9 quarters with spontaneous cure were observed. The duration of infection for Strep. agalactiae $($ mean $=270.84 \mathrm{~d})$ was significantly longer than the duration of infection for Strep. uberis $($ mean $=187.88$ d). The transmission parameters ( $\beta$ ) estimated (including $95 \%$ confidence interval) for Strep. uberis IMI and Strep. agalactiae IMI were $0.0155(0.0035-0.0693)$ and 0.0068 (0.0008-0.0606), respectively. The $\mathrm{R}_{0}$ (including
\end{abstract}

Received June 11, 2015.

Accepted October 4, 2015.

${ }^{1}$ Corresponding author: Suriyasathaporn@hotmail.com
$95 \%$ confidence interval) during the study were 2.91 (0.63-13.47) and 1.86 (0.21-16.61) for Strep. uberis IMI and Strep. agalactiae IMI, respectively. In conclusion, the transmission parameter and $\mathrm{R}_{0}$ values were not different between both pathogens; however, the duration of infection for Strep. agalactiae was longer than Strep. uberis. These suggest that Strep. uberis may have a different transmission dynamic compared with Strep. agalactiae.

Key words: Streptococcus uberis, Streptococcus agalactiae, mastitis, outbreak, duration of infection

\section{INTRODUCTION}

Bovine mastitis is considered to be one of the most economically important diseases in the dairy industry (Fetrow et al., 2000; Pyörälä, 2002; Seegers et al., 2003; Petrovski et al., 2006), due to reduced milk production and lower milk quality, increased cost of labor, drugs, and veterinary services (Wang et al., 1999). The Streptococcus spp., including Streptococcus agalactiae and Streptococcus uberis, are major mastitis pathogens in the dairy industry worldwide (Zadoks and Fitzpatrick, 2009; Shome et al., 2012).

Streptococcus agalactiae is a highly contagious obligate pathogen causing a long duration of subclinical mastitis, especially when the disease has not been identified (National Mastitis Council, 1998). Transmission of this pathogen occurs directly from an infected udder to an uninfected udder during the milking process, via milkers' hands, liners, and common udder cloths (Keefe, 1997). Streptococcus uberis is considered to be an environmental pathogen, as its primary reservoir and the source of new IMI is the environment (Radostits et al., 1994). However, cow-to-cow transmission of Strep. uberis has also been reported (Phuektes et al., 2001; Zadoks et al., 2003; McDougall et al., 2004; Pullinger et al., 2007; Rato et al., 2008). Zadoks et al. (2001) suggested that the outbreak of Strep. uberis mastitis in their study was caused by contagious transmission. 
For infectious pathogens, mathematical models are useful for analysis of the dynamics of the diseases (Anderson and May, 1992). Mathematical models are used to describe the transmission of the disease, and can be used for the estimation of $\mathrm{R}_{0}$, the basic reproductive number (Zadoks et al., 2002). $\mathrm{R}_{0}$, the average number of secondary infections resulting from the introduction of one infectious individual into a fully susceptible population (Anderson and May, 1992; Diekmann and Heesterbeek, 2000), depends on the duration of infection and the transmission rate $(\beta)$. The velocity of an outbreak is the rate of change from susceptible to infected individuals in a population. The $\mathrm{R}_{0}$ has to be $>1$ for sustained transmission to occur and for the pathogen to spread through a population (Anderson and May, 1992).

Mastitis control interventions are intended to reduce the duration of infection and prevent new infections. However, information about the duration of infection, transmission rate, and basic reproductive number of mastitis for Strep. agalactiae and Strep. uberis in natural outbreaks is limited, especially in relation to poor herd management. Therefore, the objective of the present study was to evaluate the values of transmission parameter $(\beta)$, duration of infection, and basic reproductive number $\left(\mathrm{R}_{0}\right)$ of Strep. agalactiae and Strep. uberis in herds with poor mastitis control programs.

\section{MATERIALS AND METHODS}

\section{Herds and Animals}

A 10-mo longitudinal investigation was performed using data collected from 2 smallholder dairy herds in Phatung dairy cooperative, Chiang Mai, Thailand, from January to October 2013. On November 2012, both herds were required by their cooperative to improve of their milk quality because they had a bulk milk somatic cell counts (BMSCC) of more than 1,000,000 cells/ $\mathrm{mL}$ for a month. The herds were investigated by the Faculty of Veterinary Medicine, Chiang Mai University, through the udder health section of the clinical rotation course for fifth-year veterinary students. Data on cow characteristic, herd management, milking management, and milking machines were collected. All quarters were tested for subclinical mastitis using the California mastitis test, and milk samples from quarters with California mastitis test score $\geq 1$ were aseptically collected for bacterial identification. Results showed that both herds had mastitis outbreaks, one from Strep. uberis and the other from Strep. agalactiae. After the pathogen identification and data evaluation, the mastitis problems caused by Strep. uberis and Strep. agalactiae outbreaks were reported to the veterinary team. Adjusting herd management based on mastitis control strategies had been recommended to the owners to improve their milk quality. On January 2013, a local veterinarian reported that BMSCC remained higher than 600,000 cells $/ \mathrm{mL}$ in both herds, and found that milking routines had not been improved.

In both Strep. uberis and Strep. agalactiae outbreak herds, cows were crossbred Holstein-Friesians and were housed in tie-stall barns with concrete floors. Lactating cows were milked twice daily with bucket type milking machines. Poor husbandry and milking practice without regular maintenance of the milking machines were observed in both herds. Use of individual paper towels, immediately postmilking teat disinfection, segregating infected cows and milking them last, dry cow therapy, and routine culling of cows with chronic or recurrent mastitis were not practiced. Antibiotic treatments of clinical cases of mastitis were applied for selected cows by a local veterinarian. The Strep. uberis outbreak herd had 31 milking cows with an average milk production of $6.5 \mathrm{~kg} / \mathrm{d}$, whereas the herd with Strep. agalactiae outbreak had 19 milking cows with an average milk production of $8.7 \mathrm{~kg} / \mathrm{d}$. The BMSCC throughout the 10-mo study period had been more than 600,000 cells/ $\mathrm{mL}$.

\section{Milk Sample Collection and Bacteriologic Analysis}

Quarter milk samples were aseptically collected from all quarters of all lactating cows at approximately monthly intervals from January to October 2013. Data on clinical mastitis, antibiotic treatment and dates of calving, dry-off, or culling were recorded. Bacteriological procedures were conducted according to National Mastitis Council standards (Harmon et al., 1990). Milk samples $(0.01 \mathrm{~mL})$ were cultured onto one quarter of a $5 \%$ blood agar plate and incubated for up to $48 \mathrm{~h}$ at $37^{\circ} \mathrm{C}$. Colony morphology and biochemical examination were used for bacterial identification. Preliminary identification of Strep. uberis and Strep. agalactiae was based on colony morphology and esculin hydrolysis on Edward's medium. The number of colony-forming units was recorded for all samples.

\section{Definition of Intramammary Infection}

The definition of IMI was determined according to Lam et al. (1996a) with slight modifications. A quarter was considered to have an IMI when $\geq 1,000 \mathrm{cfu} / \mathrm{mL}$ of the pathogen was cultured from a single sample, or when $\geq 100 \mathrm{cfu} / \mathrm{mL}$ was cultured from a sample of a clinical case. Samples containing more than 3 bacterial species were considered contaminated and were not informative of IMI status. A previously infected quarter 
was considered recovered from IMI for a species if none of the above definitions were found and the sample was free from the original pathogen (Zadoks et al., 2001). A quarter was eligible for a new episode of infection after it had recovered from IMI (Zadoks et al., 2003). When the IMI at the first sampling period of a new lactation was caused by the same pathogen as before drying off, it was defined as a persistent infection of the same episode of infection due to the absence of dry cow therapy.

\section{Duration of Infection}

Duration of infection was calculated based on the midpoint estimation method previously described by Zadokset al. (2003). Dates for the start and end of IMI were estimated halfway between the 2 adjacent sampling dates. Duration of infection was defined as the interval from the midpoint between the last negative and first positive sample and the midpoint between the last positive and first negative sample. For IMI that was first detected at the first time of study, at calving, or as a clinical mastitis finding, the sample date was assumed to be the date of onset of infection. For IMI that was last detected at drying off or at culling, the sample date was taken as the endpoint of infection.

Infection status was defined into 4 categories:

- Cure: infections with starting and ending point of infection known, as infection ended with spontaneous cure;

- L-censored cure: infections with only the ending point of infection known, as infections occurred before the study commenced (left-censored) and ended with spontaneous cure;

- R-censored: infections with only the starting point of infection known, as infection remained at the end of study (right-censored) or ended due to drying off, culling, or antibiotic treatment;

- L-R censored: infections without starting and ending point of infection known, as infections occurred before the study commenced (left-censored), and remained at the end of the study (right-censored) or ended due to drying off, culling, or antibiotic treatment.

\section{Statistical Analysis}

Incidence rates were calculated as the number of new IMI per quarter days at risk (Barkema et al., 1998; Zadoks et al., 2001), and then reported as a normalized value by using the denominator (30 quarter-days at risk). Statistical analysis was conducted using SAS version 9.3 (SAS Institute Inc., Cary, NC). The durations of infection for Strep. uberis IMI and Strep. agalactiae
IMI were estimated using Kaplan-Meier survival curves, accounting for censored observations. Potential differences in the Kaplan-Meier survival function between Strep. uberis IMI and Strep. agalactiae IMI were tested using log-rank test. Means of duration of infection for each species were estimated from the distribution of the failure times. To compute the mean of the KaplanMeier if the longest observation is censored, the longest survival time should be treated as an event (Miller, 1981). Due to the underestimation on mean duration of infection from Kaplan-Meier survival function, a period of $30 \mathrm{~d}$ was added to the longest survival time, and treated as an event before the calculation.

The spread of Strep. uberis and Strep. agalactiae through the population was determined by transmission parameter, $\beta$, the probability per unit of time that one infectious quarter will infect another quarter, assuming that all other quarters are susceptible (Lam et al., 1996a). To estimate the parameter $\beta$, a susceptible-infected-susceptible model for the transmission of the pathogen between quarters was used. The infected quarters are capable of being re-infected after recovery. Therefore, the population was separated into S (noncases) and I (cases) states. New quarter infections with the pathogen were assumed to occur at the rate $\beta \times \mathrm{S} \times \mathrm{I} / \mathrm{N}$, where $\beta$ is the transmission parameter, $S$ the number of susceptible quarters, I the number of infected quarters, and $\mathrm{N}$ is the total number of quarters (Zadoks et al., 2002). Transmission parameters $\left(\beta_{\mathrm{i}}\right)$ were estimated from a generalized linear model with the number of new IMI events in each sampling interval (IMI, the number of new IMI divided by the sampling interval) as the outcome, a log link, assuming a Poisson error distribution, and $\ln (\mathrm{S} \times \mathrm{I} / \mathrm{N})$ used as the offset (Lam et al., 1996a; Zadoks et al., 2002; Mweu et al., 2012; Barlow et al., 2013),

$$
\varepsilon[\ln (\mathrm{IMI})]=\beta_{i}^{\prime}+\ln (\mathrm{S} \times \mathrm{I} / \mathrm{N}),
$$

where $\varepsilon=$ expected value, $\beta^{\prime}=\ln (\beta), S=$ number of susceptible quarter days, I = number of infected quarter days, and $\mathrm{N}=$ total number of quarter days in each interval. The transmission parameters (including 95\% confidence intervals) for Strep. uberis and Strep. agalactiae were estimated for the individual herds. Data used for the analysis are shown in Table 1. The better fitted model for the I state was determined by comparing Akaike information criterion (AIC) values between models with and without the I state, and a model with lower AIC was determined as the better model.

$R_{0}$ varies with $\beta_{\mathrm{i}}$ (Lam et al., 1996a) as

$$
\mathrm{R}_{0}=\beta_{\mathrm{i}} \times \tau,
$$


Table 1. Data from Streptococcus uberis outbreak herd and Streptococcus agalactiae outbreak herd showing the number of susceptible quarter days, infected quarter days, total number of quarter days, and number of new IMI of Streptococcus uberis and Streptococcus agalactiae during a 10-mo observation period containing 9 consecutive sampling intervals (sampling time 1 was baseline)

\begin{tabular}{|c|c|c|c|c|c|c|c|c|c|c|}
\hline $\begin{array}{l}\text { Sampling } \\
\text { interval }\end{array}$ & \multicolumn{5}{|c|}{ Streptococcus uberis IMI $^{1}$} & \multicolumn{5}{|c|}{ Streptococcus agalactiae $\mathrm{IMI}^{1}$} \\
\hline 2 & 38 & 90.5 & 11.5 & 102 & 7 & 23 & 27.5 & 28.5 & 56 & 0 \\
\hline 3 & 33 & 82 & 18 & 100 & 12 & 32 & 26.5 & 28.5 & 55 & 4 \\
\hline 4 & 30 & 78.5 & 19 & 97.5 & 4 & 32 & 26.5 & 29.5 & 56 & 1 \\
\hline 8 & 35 & 53 & 16 & 69 & 8 & 33 & 34 & 19 & 53 & 4 \\
\hline 9 & 37 & 53 & 15 & 68 & 4 & 37 & 39 & 20 & 59 & 1 \\
\hline
\end{tabular}

${ }^{1} \mathrm{~S}=$ number of susceptible quarters (the total number of susceptible quarter days divided by number of days in the interval); $\mathrm{I}=$ number of infected quarters (the total number of infected quarter days divided by number of days in the interval); $\mathrm{N}=$ number of quarters (the total number of quarter days divided by number of days in the interval); IMI = number of new IMI.

where $\tau=$ the mean duration of the infectious period, which equals $1 / \alpha\left(\alpha=\right.$ the cure rate of IMI). The $\mathrm{R}_{0}$ was calculated for each of individual herds for Strep. uberis and Strep. agalactiae IMI. The $95 \%$ confidence interval lower and upper limits were calculated for $\mathrm{R}_{0}$ estimates:

$$
\operatorname{Exp}\left[\ln \left(\mathrm{R}_{0}\right) \pm 1.96 \times \mathrm{SD}\left(\ln \left(\mathrm{R}_{0}\right)\right],\right.
$$

where SD $\left[\ln \left(\mathrm{R}_{0}\right)\right]=\sqrt{ } \operatorname{Var}\left[\ln \left(\mathrm{R}_{0}\right)\right]$, Var $\left[\ln \left(\mathrm{R}_{0}\right)\right]=$ $\operatorname{Var}\left[\ln \left(\beta_{\mathrm{i}}\right)\right]+\operatorname{Var}[\ln (\tau)]+2$ Covar (Covaris equal to zero), $\operatorname{Var}\left[\ln \left(\beta_{\mathrm{i}}\right)\right]=\left[\mathrm{SD}\right.$ (estimate of $\left.\left.\beta_{\mathrm{i}}\right)\right]^{2}$, and $\operatorname{Var}[\ln$ $(\tau)]=\{\operatorname{SD}[\ln (\tau)]\}^{2}$.

\section{RESULTS}

A total of 1,397 quarter milk samples were collected from the 2 herds. For the Strep. uberis outbreak herd, 851 quarter samples were taken from 31 cows including 4 new cows and 8 culling cows during the study period, and 546 samples were taken from 19 cows including 3 new cows and 1 culling cows during the study period for the Strep. agalactiae outbreak herd. Most cows were culled because of reproductive problems. During the study, 14 and 9 cows in Strep. uberis and Strep. agalactiae outbreak herds, respectively, were dried off with the duration ranging between 1 to 5 mo. Antibiotic treatment was administered on a cow with clinical mastitis in the Strep. uberis outbreak herd. The treated animal was not included for the calculation.

For the Strep. uberis outbreak herd, the observed numbers of total quarters ranging from 96 to 104 during January to June decreased to 62 to 76 during July to October. The prevalence of Strep. uberis IMI at starting was 0.33 (9 out of 27) and 0.125 (13 out of 104) for cow and quarter levels, respectively, and most infected cows
(66.7\%) had only one Strep. uberis IMI quarter. For the entire study, 12 from 31 cows were free from Strep. uberis throughout the study period, but 19 cows had Strep. uberis IMI including 5, 5, 4, and 5 cows, with their 4, 3, 2, and 1 IMI quarters, respectively. From 10 monthly sampling times, a mean interval calculated from 9 sampling intervals was $32.6 \mathrm{~d}$ (SD 3.8). Figure 1 shows the quarter prevalence of Strep. uberis IMI, numbers of new infections, spontaneous cures, and censored quarters due to culling, treatment, and drying off during each sampling time. Prevalence (proportion of infected quarters per 30 quarter-days at risk) for the entire study ranged from 0.09 in third sampling time to 0.22 in eighth sampling time. From a total of 56 new Strep. uberis infections, the new IMI occurred mainly in April $(\mathrm{n}=12)$, July $(\mathrm{n}=9)$, and September $(\mathrm{n}=8)$. Spontaneous cure of infection was observed in 28 quarters, whereas end of infection from drying off, culling, or treatment was observed in 27 quarters. The rates of spontaneous cure (percentage of cure quarters per total infected quarters) between sampling times ranged from $0 \%$ in 7 th and 9 th sampling times to $47 \%$ in sixth sampling time.

For Strep. agalactiae outbreak herd, the observed numbers of total quarters ranged from 54 to 63 , except in September $(\mathrm{n}=47)$ and August $(\mathrm{n}=51)$. The prevalence of Strep. agalactiae IMI at starting was 0.63 (10 out of 16) and 0.36 (23 out of 63 ) for cow and quarter levels, respectively. For the entire study, 5 from 19 cows were free from Strep. agalactiae throughout the study period including 3 newly introduced cows. Six cows experienced Strep. agalactiae IMI in all quarters. During the 10-mo observation period at a mean interval of 31.4 d (SD 4.6), spontaneous cure of infection was observed in 9 quarters, whereas right-censored IMI due to drying off or culling was observed in 21 quarters. Prevalence 


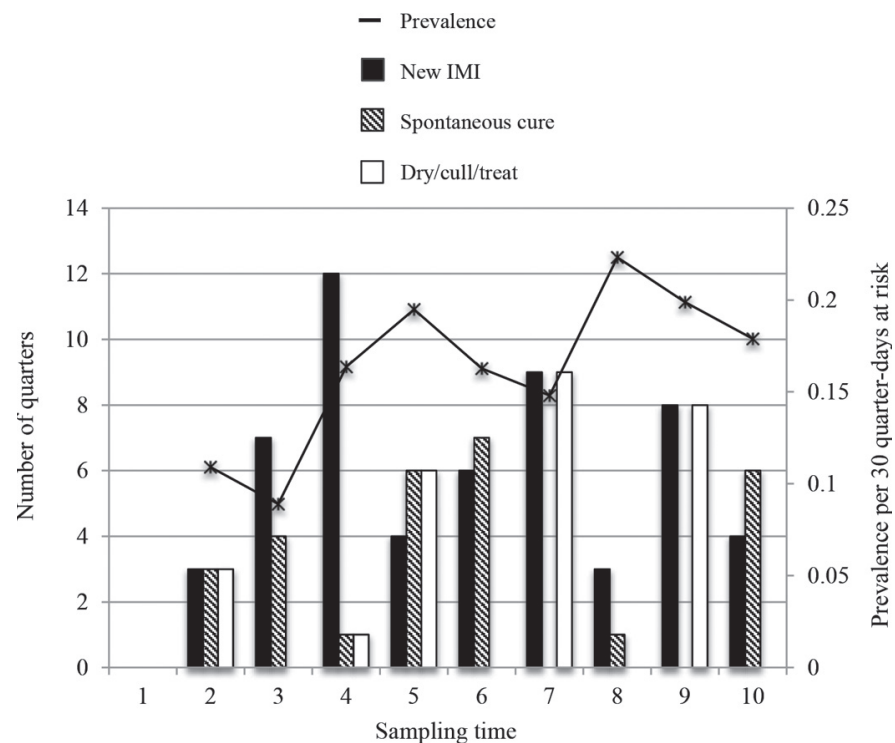

Figure 1. Quarter prevalence (proportion of infected quarters per 30 quarter-days at risk), numbers of new infections, spontaneous cures, and censored quarters due to culling, treatment, and drying off during each sampling time in a Streptococcus uberis outbreak herd.

during the study ranged from 0.27 in tenth sampling time to 0.66 in the third sampling time (Figure 2). From a total of 26 new Strep. agalactiae infections, the new IMI occurred mainly in February $(\mathrm{n}=9)$ ), April $(\mathrm{n}$ $=4)$, June $(\mathrm{n}=4)$, and September $(\mathrm{n}=4)$. The rates of spontaneous cure between sampling times ranged from $0 \%$ in $3 \mathrm{rd}, 4 \mathrm{th}, 8 \mathrm{th}$, and 9 th sampling times to $14.3 \%$ in 10 th sampling time.

During the 10-mo sampling times (contained 9 sampling intervals), the majority of cases occurred in a limited time interval, covering sampling interval 3 for Strep. uberis outbreak herd and sampling interval 1 for Strep. agalactiae outbreak herd. These are the outbreak period for each herd.

The average of incidence rates of Strep. uberis and Strep. agalactiae IMI (number of new IMI per quarterday at risk) were 0.0026 and 0.0029 , respectively. Incidence rates of new IMI per 30 quarter-days at risk by sampling time for both herds are shown in Figure 3. Overall incidence rates of new IMI per 30 quarter-days at risk of Strep. uberis and Strep. agalactiae outbreak herds were 0.08 and 0.09 , respectively. Ranges of Strep. agalactiae incidence rates $(0-0.22)$ were broader than that of Strep. uberis (0.03-0.13).

Duration of infection was estimated for 69 infections in Strep. uberis outbreak herd. Infections that were present at the start or the end of the study, and infections in animals that were dried off, culled or treated (censored) were observed in 48 of 69 infections (70\%). The duration of infections ranged from 15.5 to $293 \mathrm{~d}$.

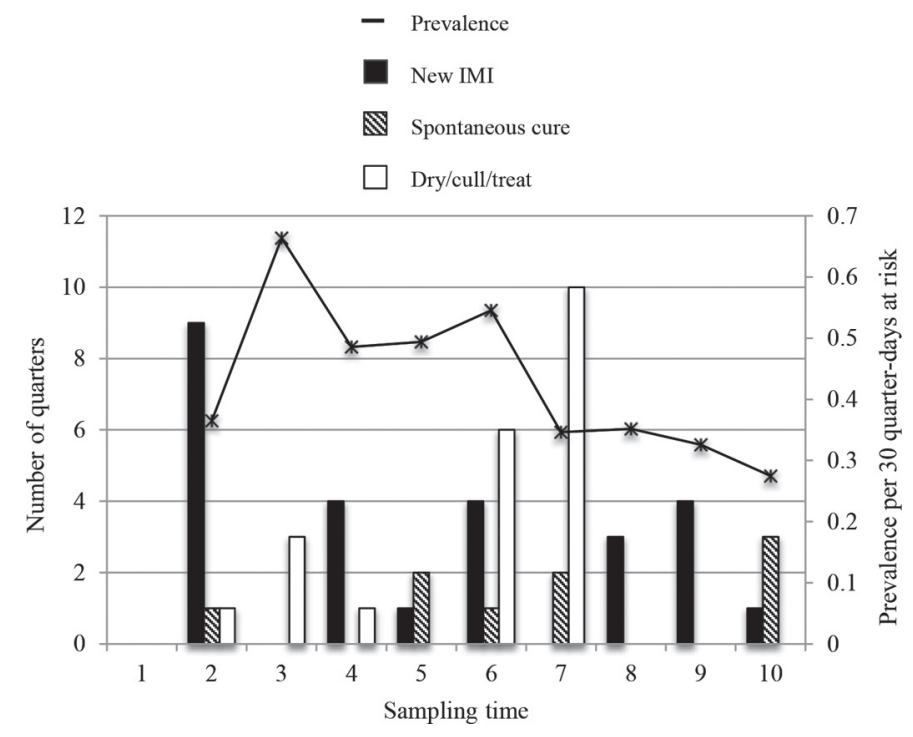

Figure 2. Quarter prevalence (proportion of infected quarters per 30 quarter-days at risk), numbers of new infections, spontaneous cures, and censored quarters due to culling, treatment, and drying off during each sampling time in a Streptococcus agalactiae outbreak herd.

The mean duration of Strep. uberis IMI was $187.88 \mathrm{~d}$ (SE 23.29). In Strep. agalactiae outbreak herd, duration of infection was estimated for 49 infections. Infections that were present at the start or the end of the study, and infections in animals that were dried off, or culled (censored) were observed in 43 of 49 infections (88\%). The duration of infections ranged from 18 to $283 \mathrm{~d}$. The mean duration of Strep. agalactiae IMI was 270.84 d (SE 17.29).

Distribution of duration of infection in 4 infection categories (cure, L-censored cure, R-censored, and L-R

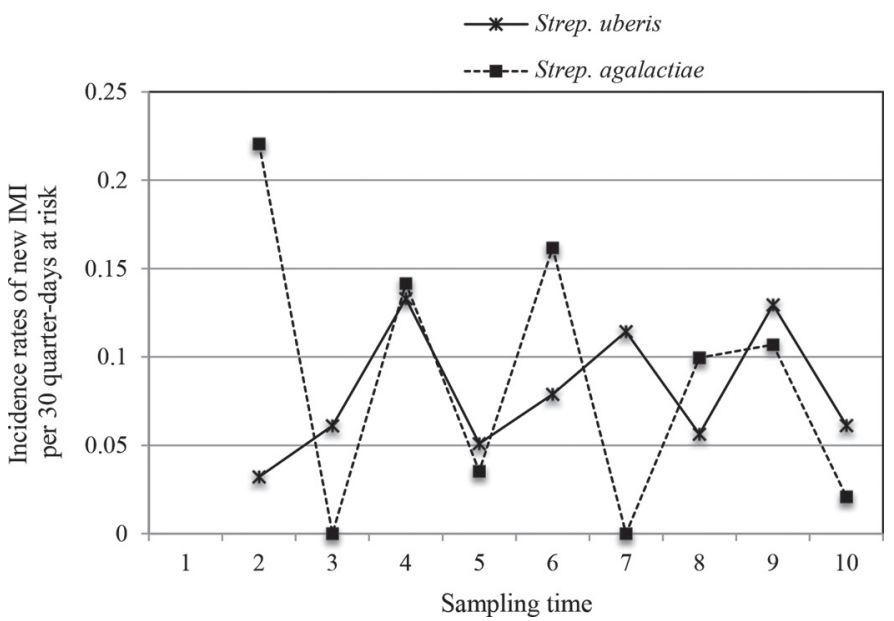

Figure 3. Incidence rates of new IMI per 30 quarter-days at risk by sampling time for both herds. Strep. = Streptococcus. 


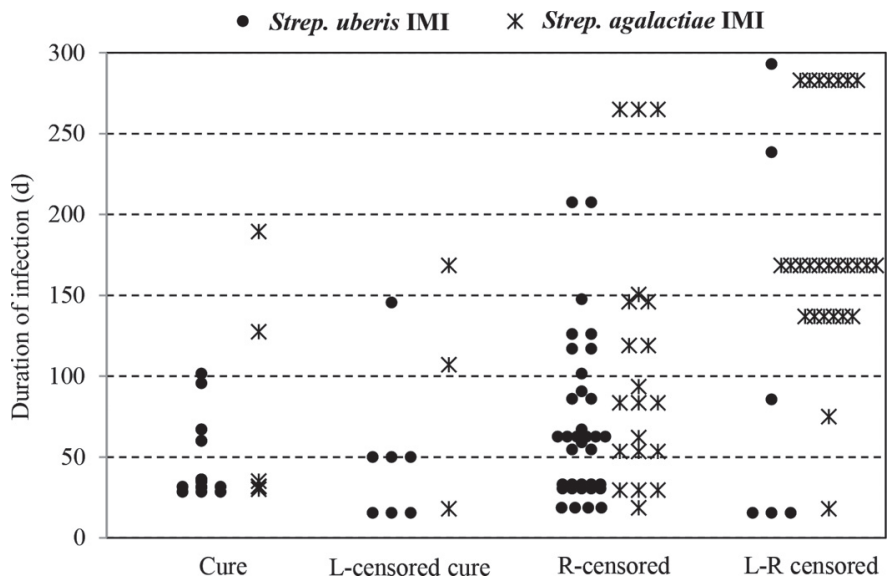

Figure 4. Distribution of duration of infection in 4 infection categories [cure, left (L)-censored cure, right (R)-censored, and left-right (L-R) censored] for Streptococcus uberis and Streptococcus agalactiae IMI

censored) for Strep. uberis and Strep. agalactiae IMI are shown in Figure 4. Most infections caused by Strep. agalactiae were in R-censored $(20 / 49,41 \%)$ and L-R censored $(20 / 49,41 \%)$, which ranged from 18.5 to 265 d and 18 to 283 d, respectively. Most Strep. uberis infections were in R-censored $(35 / 69,51 \%)$ and cure $(21 / 69$, $30 \%$ ), ranging from 18.5 to $207.5 \mathrm{~d}$ and 28.5 to $95.5 \mathrm{~d}$, respectively.

A Kaplan-Meier curve on duration of Strep. uberis IMI and Strep. agalactiae IMI is shown in Figure 5. Approximately $80 \%$ of Strep. agalactiae were censored at the end of the study, therefore most Strep. agalactiae IMI could not be defined as spontaneous cures. In contrast, approximately $50 \%$ of Strep. uberis IMI spontaneously cured within $100 \mathrm{~d}$ following the start of the IMI. When comparing the $20 \%$ of the cured population, the survival time, indicating duration of IMI with spontaneous cure, for Strep. uberis (approximately 36 d) was shorter than that for Strep. agalactiae (approximately $190 \mathrm{~d}$ ). In comparing infection duration between Strep. uberis and Strep. agalactiae using log-rank test, IMI quarters with Strep. agalactiae had significantly longer infection duration than IMI quarters infected with Strep. uberis $(P<0.05)$.

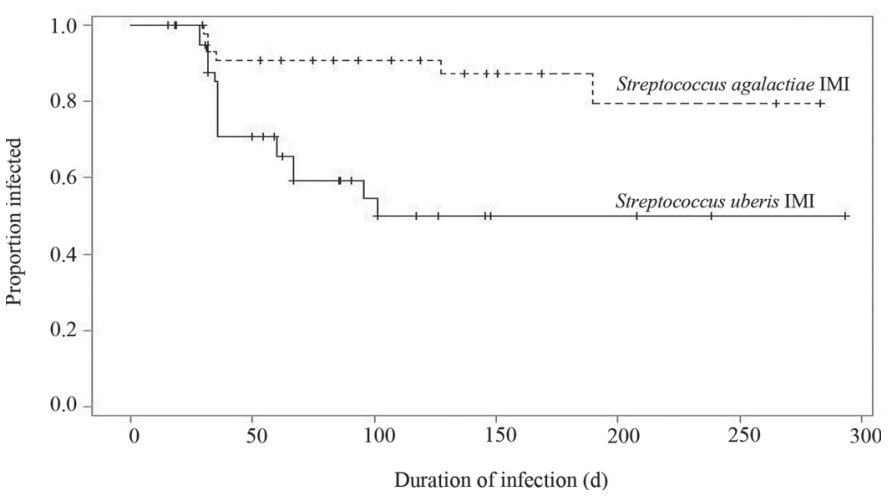

Figure 5. Kaplan-Meier survival curve of duration of Streptococcus uberis IMI (full line) and Streptococcus agalactiae IMI (dashed line) observed during a 10-mo period. Lines are significantly different (log rank test, $P<0.05) ;+$ indicates censoring of observation.

The model including the number of infected quarters (I) was the lower AIC value, indicating the better fit of the model compared with the model without this parameter. The transmission parameter $(\beta)$ estimates (including $95 \%$ confidence interval lower and upper limits) for Strep. uberis IMI and Strep. agalactiae IMI were $0.0155(0.0035-0.0693)$ and $0.0068(0.0008-0.0606)$, respectively. The estimates for transmission parameters, mean duration of infection, and basic reproductive number $\left(\mathrm{R}_{0}\right)$, calculated from the matching $\beta$ and the mean duration of infection period, are shown in Table 2 . The $\mathrm{R}_{0}$ (including $95 \%$ confidence interval) during the study were $2.91(0.37-22.87)$ and $1.86(0.12-28.59)$ for Strep. uberis IMI and Strep. agalactiae IMI, respectively. The $\mathrm{R}_{0}$ during the study exceeded 1 for both pathogens, whereas $\mathrm{R}_{0}$ for Strep. uberis IMI was higher than $\mathrm{R}_{0}$ for Strep. agalactiae IMI. The $95 \%$ confidence intervals for $\mathrm{R}_{0}$ of Strep. uberis and Strep. agalactiae overlapped, and they were not significantly different.

\section{DISCUSSION}

This study uses longitudinal serial sampling and mathematical modeling to describe the transmission dynamics of Strep. agalactiae and Strep. uberis in 2 separate herds. Both outbreak herds had poor mastitis

Table 2. Estimates of transmission parameters $(\beta)$ including $95 \%$ confidence interval lower and upper limits, mean duration of infection (SE), and basic reproductive number $\left(\mathrm{R}_{0}\right)$ including $95 \%$ confidence interval lower and upper limits, for Streptococcus uberis and Streptococcus agalactiae IMI during the study

\begin{tabular}{lcc}
\hline Parameter & Streptococcus uberis & Streptococcus agalactiae \\
\hline$\beta(95 \% \mathrm{CI})$ & $0.0155(0.0035-0.0693)$ & $0.0068(0.0008-0.0606)$ \\
Mean duration of IMI (SE) & $187.88(23.29)^{*}$ & $270.84(17.29)^{*}$ \\
$\mathrm{R}_{0}(95 \% \mathrm{CI})$ & $2.91(0.63-13.47)$ & $1.86(0.21-16.61)$ \\
\hline
\end{tabular}

*Indicates significantly different at $P<0.05$ using log-rank test. 
control management: for example, using the same cloth to wash or dry all cows, no postmilking teat dipping (PMTD), no dry cow therapy, no segregating infected cows and milking them last, and no culling of cows with chronic mastitis. The result of our previous study in the Strep. uberis herd using pulsed-field gel electrophoresis (PFGE) showed that most isolates of Strep. uberis (9 of 12) from the first sampling time belonged to the same PFGE type (Leelahapongsathon and Suriyasathaporn, 2015), supporting cow-to-cow transmission of a dominant PFGE type both within and between cows, which is generally reported in the case of contagious mastitis pathogens such as Strep. agalactiae and Staphylococcus aureus (Lam et al., 1996b; Baseggio et al., 1997; Wang et al., 1999). This might indicate that the transmission characteristics of both pathogens in this study were comparable.

Incidence rates of Strep. uberis and Strep. agalactiae IMI were in similar ranges, but higher than the rates previously described for both pathogens causing clinical mastitis (Barkema et al., 1998) and for Strep. uberis IMI (Zadoks et al., 2001). In this study, the Reed-Frost transmission function was estimated, and improved goodness of fit of the model that included the number of infected quarters suggests cow-to-cow transmission of Strep. uberis rather than pathogen exposure from the environment. In addition, inadequate mastitis control programs in both herds were at known risk factors associated with increased IMI and contagious transmission (Dargent-Molina et al., 1988; Mungube et al., 2004).

The transmission parameter $(\beta)$ for Strep. uberis infection was higher than the transmission parameter for Strep. agalactiae infection, whereas higher prevalence and longer duration of infection were observed with Strep. agalactiae. High prevalence with low number of new infections can occur when infections have long duration (Zadoks et al., 2002), as was observed in the Strep. agalactiae herd. The transmission parameter is related to an effective contact between infected and susceptible subjects that would be sufficient to lead to a new infection (Abbey, 1952). The effective contact depends on the method of transmission (Vynnycky and White, 2010). Streptococcus agalactiae is considered as a highly contagious obligate pathogen of the bovine mammary gland (Keefe, 1997). Intramammary infections occur primarily during milking, when milk from an infected cow comes into contact with the teat end of an uninfected cow. The infection is spread by contaminated milk on milking equipment, towels, or milker's hands. On the other hand, Strep. uberis infections can originate from exposure to environmental sources and spread from cow-to-cow during the milking process
(Zadoks et al., 2003). This characteristic provides for both contagious and noncontagious transmission, the latter occurring at any times including other sources than that during milking. A combination of contagious transmission and environmental exposure may increase the effective contact for Strep. uberis infection. The lower transmission parameter of Strep. agalactiae was unexpected because the herd did not perform proper milking management such as using separate udder cloths for each cow and PMTD (Neave et al., 1969; Pankey et al., 1983; Boddie and Nickerson, 1997).

The transmission parameter of mastitis pathogens has been estimated in a limited number of reports. White et al. (2006) reported the estimation of $\beta$ for major gram-positive pathogens with or without PMTD, ranging from 0 to 0.089. Estimates of $\beta$ for Strep. uberis from a single herd ranged from 0.005 to 0.246 (Zadoks et al., 2001).

The duration of infection in the present study might have been underestimated as some cows could have been infected before starting observations began (leftcensored) and some remained infected at the end of study or end of infection due to drying off, culling, or antibiotic treatment (right-censored), even if $30 \mathrm{~d}$ was added to the longest right-censored events to inflate the estimated survival time. A period of $30 \mathrm{~d}$ was assumed from the longest duration of Strep. uberis infection from the previous studies (Todhunter et al., 1995; Zadoks et al., 2003; Pullinger et al., 2007). Durations of Strep. uberis infection ranged between 50 to $260 \mathrm{~d}$ in a UK study (Pullinger et al., 2007), 1 to $309 \mathrm{~d}$ in a Dutch study (Zadoks et al., 2003), and 1 to $370 \mathrm{~d}$ in a US study (Todhunter et al., 1995). Our longest duration of Strep. uberis infection, after adding $30 \mathrm{~d}$, was similar to that reported by Zadoks et al. (2003), and in between those reported by Pullinger et al. (2007) and Todhunter et al. (1995). However, a longer duration of infection was observed in Strep. agalactiae infection when compared with Strep. uberis infection. As shown in Figure 4, most infections caused by Strep. agalactiae were not spontaneously cured, and this supports the study of Keefe (1997) showing that Strep. agalactiae infection has a very low spontaneous cure rate and therefore needs to be treated with antibiotics. In this study, the spontaneous cure rate of Strep. uberis infection was higher than that of Strep. agalactiae. The spontaneous cure rate without treatment of Strep. uberis infection was almost $50 \%$ (Kirk, 1998), and $45.7 \%$ of most streptococcal IMI other than Strep. agalactiae were spontaneously cured (Hogan and Smith, 2003). Craven (1987) suggested that the immune mechanism of the udder could be stimulated to enhance spontaneous elimination of infection. 
The confidence interval of $\mathrm{R}_{0}$ included 1 for both Strep. agalactiae and Strep. uberis infections. When $\mathrm{R}_{0}$ $<1$, only minor outbreaks occur; if $\mathrm{R}_{0}>1$, major outbreaks are possible, and minor outbreaks can still occur by chance (DeJong and Diekmann, 1992; DeJong et al., 1994). The infections of Strep. agalactiae and Strep. uberis were observed throughout the 10-mo study period in each herd, and support our observation that if $\mathrm{R}_{0}$ equal unity the infection is likely to persist in the population (Vynnycky and White, 2010), which suggests the difficulty of controlling the outbreak without any control methods. The main input components of $\mathrm{R}_{0}$ are the rate of new infections and duration of infections (Zadoks et al., 2002). Thus, $\mathrm{R}_{0}$ is a summary indicator of the efficacy of mastitis control strategies. Calculation of $R_{0}$ has been used to estimate the effectiveness of PMTD during an outbreak of Staphylococcus aureus mastitis in a dairy herd (Lam et al., 1996a). The $\mathrm{R}_{0}$ value for undipped quarters (range from 1.09 to 7.55) was higher than the $\mathrm{R}_{0}$ value for dipped quarters (range from 0.27 to 1.41). This was in agreement with our observations that without mastitis control strategies the outbreaks of mastitis were persistent.

In the study of the epidemiology of mastitis outbreaks, the mathematical model can provide the number for evaluating the transmission of the infection. However, the use of molecular technique can determine variability in the strain of the pathogen. The combination of mathematical and molecular approaches can support the understanding of the difference of transmission dynamic between strains of each species, especially for Strep. uberis, for which the mode of transmission can be characterized as intermediate between contagious and environmental (Zadoks et al., 2001). Thus, the mathematical and molecular techniques both need to be used to identify the epidemiological problem and investigate the nature of transmission of specified pathogens. In addition, parameter estimates might be improved from longer observational studies or by studying more herds or larger herd sizes.

\section{CONCLUSIONS}

The persistent infections of both Strep. agalactiae and Strep. uberis that consequently infect susceptible quarters were characterized as contagious mastitis. The transmission parameter $(\beta)$ for Strep. uberis infection was higher than that for Strep. agalactiae infection, indicating higher infection rate of Strep. uberis. Longer duration of infection was observed with Strep. agalactiae with a lower spontaneous cure rate when compared with Strep. uberis. $\mathrm{R}_{0}$ during the study were not different between either pathogens.

\section{ACKNOWLEDGMENTS}

This research was supported by the Royal Golden Jubilee Ph.D. Program (The Thailand Research Fund, Bangkok, Thailand).The authors thank Wantanwa Mongkol and Tanittian Panyamongkol (Department of Food Animal Clinics, Faculty of Veterinary Medicine, Chiang Mai University, Chiang Mai, Thailand).

\section{REFERENCES}

Abbey, H. 1952. An examination of the Reed-Frost theory of epidemics. Hum. Biol. 24:201-233.

Anderson, R. M., and R. M. May. 1992. Infectious diseases of humans: Dynamics and control. Oxford University Press, Oxford, UK.

Barkema, H. W., Y. H. Schukken, T. J. G. M. Lam, M. L. Beiboer, H. Wilmink, G. Benedictus, and A. Brand. 1998. Incidence of clinical mastitis in dairy herds grouped in three categories by bulk milk somatic cell count. J. Dairy Sci. 81:411-419.

Barlow, J. W., R. N. Zadoks, and Y. H. Schukken. 2013. Effect of lactation therapy on Staphylococcus aureus transmission dynamics in two commercial dairy herds. BMC Vet. Res. 9:28.

Baseggio, N., P. D. Mansell, J. W. Browning, and G. F. Browning. 1997. Strain differentiation of isolates of streptococci from bovine mastitis by pulsed-field gel electrophoresis. Mol. Cell. Probes $11: 349-354$.

Boddie, R. L., and S. C. Nickerson. 1997. Evaluation of two iodophor teat germicides: Activity against Staphylococcus aureus and Streptococcus agalactiae. J. Dairy Sci. 80:1846-1850.

Craven, N. 1987. Efficacy and financial value of antibiotic treatment of bovine clinical mastitis during lactation. Br. Vet. J. 143:410-422.

Dargent-Molina, P., J. Scarlett, R. V. H. Pollock, H. N. Erb, and P. Sears. 1988. Herd-level risk factors for Staphylococcus aureus and Streptococcus agalactiae intramammary infections. Prev. Vet. Med. 6:127-142.

DeJong, M. C. M., and O. Diekmann. 1992. A method to calculate, for computer-simulated infections, the threshold value $R_{0}$ that predicts whether or not the infection will spread. Prev. Vet. Med. $12: 269-285$.

DeJong, M. C. M., O. Diekmann, and J. A. P. Heesterbeek. 1994. The computation of $\mathrm{R}_{0}$ for discrete-time epidemic models with dynamic heterogeneity. Math. Biosci. 119:97-114.

Diekmann, O., and J. A. P. Heesterbeek. 2000. Mathematical Epidemiology of Infectious Diseases: Model Building, Analysis and Interpretation. John Wiley and Sons, New York, NY.

Fetrow, J., S. Stewart, S. Eicker, R. Farnsworth, and R. Bey. 2000. Mastitis: An economic consideration. Pages 3-47 in Proc. National Mastitis Council Annual Meeting, Atlanta, GA.

Harmon, R. J., R. J. Eberhart, D. E. Jasper, B. E. Langlois, and R. A. Wilson. 1990. Microbiological procedures for use in the diagnosis of bovine udder infections. Natl. Mastitis Counc. Inc., Arlington, VA.

Hogan, J. S., and K. L. Smith. 2003. Environmental streptococcal mastitis: Facts, fables, and fallacies. Pages 162-171 in Proc. National Mastitis Council Annual Meeting, Fort Worth, TX. National Mastitis Council Inc., Verona, WI.

Keefe, G. P. 1997. Streptococcus agalactiae mastitis: A review. Can. Vet. J. 38:429-437.

Kirk, J. H. 1998. Streptococcus uberis in well-managed dairy ranches. University of California-Davis Veterinary Medicine Extension.

Lam, T. J., M. C. DeJong, Y. H. Schukken, and A. Brand. 1996a. Mathematical modeling to estimate efficacy of postmilking teat disinfection in split-udder trials of dairy cows. J. Dairy Sci. 79:6270 .

Lam, T. J., L. J. Lipman, Y. H. Schukken, W. Gaastra, and A. Brand. 1996b. Epidemiological characteristics of bovine clinical mastitis caused by Staphylococcus aureus and Escherichia coli studied by DNA fingerprinting. Am. J. Vet. Res. 57:39-42. 
Leelahapongsathon, K., and W. Suriyasathaporn. 2015. An outbreak of Streptococcus uberis mastitis due to the contagious transmission in a smallholder dairy farm with poor milking management. Pages 165-167 in Proc. 14th Chulalongkorn Univ. Vet. Conf., Bangkok, Thailand. Chulalongkorn University, Bangkok, Thailand.

McDougall, S., T. J. Parkinson, M. Leyland, F. M. Anniss, and S. G. Fenwick. 2004. Duration of infection and strain variation in Streptococcus uberis isolated from cows' milk. J. Dairy Sci. 87:20622072.

Miller, R. G. 1981. Survival Analysis. John Wiley and Sons, New York, NY.

Mungube, E. O., B. A. Tenhagen, T. Kassa, F. Regassa, M. N. Kyule, M. Greiner, and M. P. O. Baumann. 2004. Risk factors for dairy cow mastitis in the central highlands of Ethiopia. Trop. Anim. Health Prod. 36:463-472.

Mweu, M. M., S. S. Nielsen, T. Halasa, and N. Toft. 2012. Annual incidence, prevalence and transmission characteristics of Streptococcus agalactiae in Danish dairy herds. Prev. Vet. Med. 106:244-250.

National Mastitis Council. 1998. Current Concepts of Bovine Mastitis. 4th ed. Natl. Mastitis Council, Madison, WI.

Neave, F. K., F. H. Dodd, R. G. Kingwill, and D. R. Westgarth. 1969 Control of mastitis in the dairy herd by hygiene and management. J. Dairy Sci. 52:696-707.

Pankey, J. W., W. N. Philpot, R. L. Boddie, and J. L. Watts. 1983 Evaluation of nine teat dip formulations under experimental challenge to Staphylococcus aureus and Streptococcus agalactiae. J. Dairy Sci. 66:161-167.

Petrovski, K. R., M. Trajcev, and G. Buneski. 2006. A review of the factors affecting the costs of bovine mastitis. J. S. Afr. Vet. Assoc. $77: 52-60$.

Phuektes, P., P. D. Mansell, R. S. Dyson, N. D. Hooper, J. S. Dick, and G. F. Browning. 2001. Molecular epidemiology of Streptococcus uberis isolates from dairy cows with mastitis. J. Clin. Microbiol. 39:1460-1466.

Pullinger, G. D., T. J. Coffey, M. C. Maiden, and J. A. Leigh. 2007. Multilocus-sequence typing analysis reveals similar populations of Streptococcus uberis are responsible for bovine intramammary infections of short and long duration. Vet. Microbiol. 119:194-204.

Pyörälä, S. 2002. New strategies to prevent mastitis. Reprod. Domest. Anim. 37:211-216.
Radostits, O. M., K. E. Leslie, and J. Fetrow. 1994. Herd health: Food animal production medicine. 2nd ed. W.B. Saunders Company, Philadelphia, PA.

Rato, M. G., R. Bexiga, S. F. Nunes, L. M. Cavaco, C. L. Vilela, and I. Santos-Sanches. 2008. Molecular epidemiology and population structure of bovine Streptococcus uberis. J. Dairy Sci. 91:45424551.

Seegers, H., C. Fourichon, and F. Beaudeau. 2003. Production effects related to mastitis and mastitis economics in dairy cattle herds. Vet. Res. 34:475-491.

Shome, B. R.. M. Bhuvana, S. D. Mitra, N. Krithiga, R. Shome, D. Velu, A. Banerjee, S. B. Barbuddhe, K. Prabhudas, and H. Rahman. 2012. Molecular characterization of Streptococcus agalactiae and Streptococcus uberis isolates from bovine milk. Trop. Anim. Health Prod. 44:1981-1992.

Todhunter, D. A., K. L. Smith, and J. S. Hogan. 1995. Environmental streptococcal intramammary infections of the bovine mammary gland. J. Dairy Sci. 78:2366-2374.

Vynnycky, E., and R. White. 2010. An Introduction to Infectious Disease Modelling. Oxford University Press, Oxford, UK.

Wang, S. M., M. A. Deighton, J. A. Capstick, and N. Gerraty. 1999. Epidemiological typing of bovine streptococci by pulsed-field gel electrophoresis. Epidemiol. Infect. 123:317-324.

White, L. J., T. J. Lam, Y. H. Schukken, L. E. Green, G. F. Medley, and M. J. Chappell. 2006. The transmission and control of mastitis in dairy cows: A theoretical approach. Prev. Vet. Med. 74:67-83.

Zadoks, R. N., H. G. Allore, H. W. Barkema, O. C. Sampimon, Y. T. Gröhn, and Y. H. Schukken. 2001. Analysis of an outbreak of Streptococcus uberis mastitis. J. Dairy Sci. 84:590-599.

Zadoks, R. N., H. G. Allore, T. J. Hagenaars, H. W. Barkema, and Y. H. Schukken. 2002. A mathematical model of Staphylococcus aureus control in dairy herds. Epidemiol. Infect. 129:397-416.

Zadoks, R. N., and J. L. Fitzpatrick. 2009. Changing trends in mastitis. Ir. Vet. J. 62:S59-S70.

Zadoks, R. N., B. E. Gillespie, H. W. Barkema, O. C. Sampimon, S. P. Oliver, and Y. H. Schukken. 2003. Clinical, epidemiological and molecular characteristics of Streptococcus uberis infections in dairy herds. Epidemiol. Infect. 130:335-349. 